\title{
Anatomical Structure of Shark Fish Digestive (Carcharhinus sorrah)
}

\author{
Ulfaricha Cahya Happyalita ${ }^{*}$, Nur Lailatul Kamila \\ Biology Department, Faculty of Science and Technology, UIN Sunan Kalijaga \\ Jl. Marsda Adisucipto No. 1 Yogyakarta 55281, Indonesia. Tel. + 62-274-540971, Fax. + 62-274-519739 \\ *Email: ulfaricha08@gmail.com
}

\begin{abstract}
This study aims to determine the anatomical structure of sharks. Sharks are members of the subclass elasmobranchii. Sharks (Carcharhinus sorrah) are shaped like terpedoit. This research was conducted using macroscopic and microscopic observations on the digestive organs of sharks (Carcharhinus sorrah). Macroscopic observation is done by looking at shapes, structures, and analyzing photos of organs. Microscopic observation was carried out by making organ preparations using paraffin method, using hematoxylin-eosin staining then observed using a microscope. Digestive organs of sharks (Carcharhinus sorrah) were observed, namely, stomach, intestine and liver.
\end{abstract}

Keywords: Anatomy, Carcharhinus sorrah, Sharks

\section{INTRODUCTION}

Indonesia is a maritime country with most of its territory in the form of oceans, this geographical condition is very beneficial because there are so many biodiversity that can be studied, especially fish species that live in the sea. Some fish species have real bones and some have cartilage (Elasmobranchii) (White et al., 2006 in Syakuracman, 2014). Cartilaginous fish in Indonesian waters totaled 221 species (Sadili et al., 2015). Cartilaginous fish are fish that have cartilage structures throughout their lives (Castro \& Huber, 1997). Cartilaginous fish (Elasmobranchii) have a larger size than hard-billed fish (Candramila, 2006). Elasmobranchii's body is not covered by scales like hard-boned fish in general but is covered by fine durian which has the same composition as teeth. Elasmobranchii has a strong jaw and is armed with sharp teeth that serve to ambush its prey. Members of the Elasmobranchii subclass are sharks. Sharks have a high diversity in Indonesia. Sharks found in Indonesian waters amount to 117 species and are found up to 150 meters deep. As many as $51 \%$ of shark species in Indonesia are found in continental exposure areas (Sadili et al., 2015). Sharks eat a variety of organisms ranging from small fish to large fish, crabs, turtles, squid, and all food debris from the ship. Sharks can eat their own kind (cannibalism) (Nontji, 1987).

The digestive organs of fish are sequentially the mouth, pharynx, esophagus, stomach, intestine, and liver, anus. The process of digesting food in fish occurs when food is swallowed and then enters the stomach through the pharynx and esophagus (Castro \& Huber, 1997). The fish hull has a size that is not too large but the fish hull has a thick and muscular wall. The fish's stomach is coated with mucus which helps in the process of digestion of food and protects the stomach wall. The fish's gastric layer is also strengthened by connective tissue and lumen (Saksena, 1999).
Foods that have been processed in the stomach then enter the intestine. The intestine is the longest organ in the digestive system of the fish and has a very elastic structure (Saksena, 1999). Fish intestines have different shapes and sizes, carnivorous fish have short and straight intestines (Castro \& Huber 1997). Another organ that is no less important in the digestive process is the liver. The liver is an organ that secretes food ingredients for the digestive process. The liver is generally brownish red, composed of liver cells (hepatocytes) (Fujaya, 2004). The liver is the largest digestive organ in the fish's body. Liver size can reach $20 \%$ of fish body weight (Castro \& Huber, 1997).

\section{MATERIALS AND METHODS}

The tools used in this study were surgical instruments, glass beakers, microtomes, slide warmers, paraffin ovens (Heraeus), binocular microscopes (Nikon YS 100 models), DSLR cameras (Canon), object glass, cover glass, calendar (paper), tweezers, and tissue. The ingredients used in this study were sharks (Carcharhinus sorrah), Bouin solution, alcohol 30\%, $40 \%, 50 \%, 60 \%, 70 \%, 80 \%, 90 \%, 96 \%$, and absolute, toluene, xylol, hematoxylin-eosin, and entellan. This study uses sharks (Carcharhinus sorrah) obtained from the south coast of Yogyakarta.

\section{RESULTS AND DISCUSSION}

Based on research conducted, the morphology of sharks observed has a large, long, and slim body shape. The total length of sharks is $65 \mathrm{~cm}$ and weighs $1.7 \mathrm{~kg}$. The body of the shark in the dorsal part has gray darkness, while the lateral part of the shark is white. 


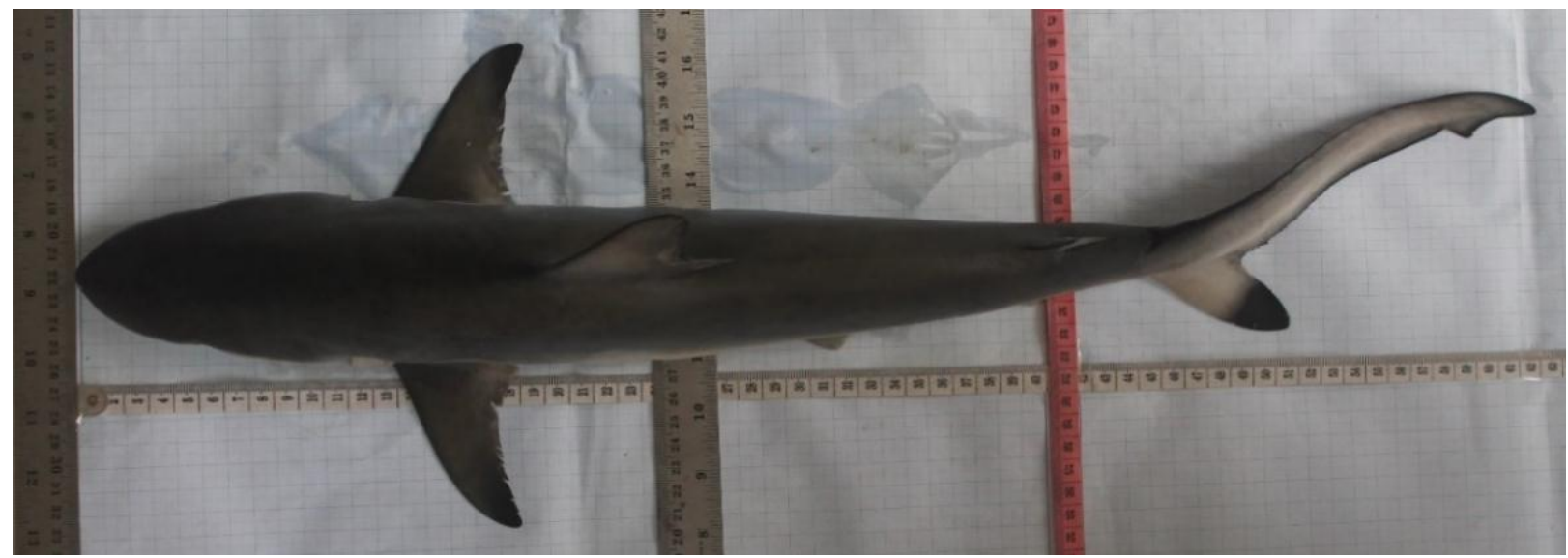

Figure 1. Dorsal section morphology of the shark.

Based on observations made, sharks have gills located on the lateral side, namely on the left and right sides of the back, the gill slits in the shark are 5 pieces, large intestine, rectum, anus.

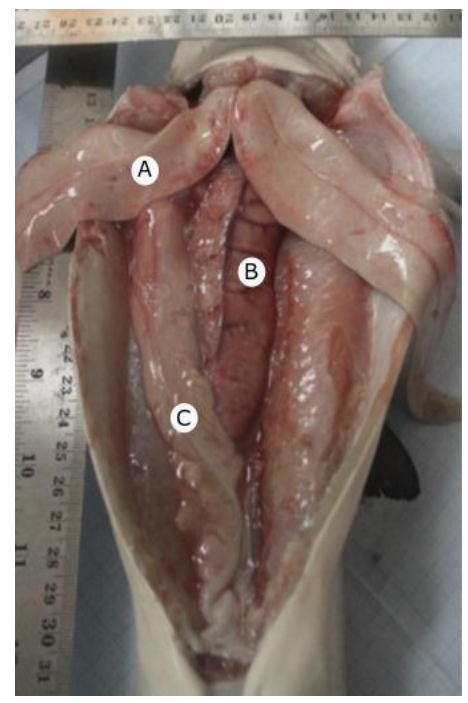

Figure 2. Anatomy of shark digestive organs (Carcharhinus sorrah) (A) Liver, (B) Stomach, (C) Intestine.

Sharks have features of a flattened head, a long, rounded snout. The ventral part of the base of the snout is a pair of nasal passages. The mouth is located in the leading edge of the bottom. A pair of large circular eyes located on the lateral part of the head.

Based on observations made, sharks have gills located on the lateral side, namely on the left and right side of the back, the gill gaps in sharks are 5 pieces; large intestine, rectum, anus. The digestive organs of the shark (Carcharhinus sorrah) covering the intestine and liver stomach were observed in a macroanatomy and photographed using a camera.

\section{Gastric Anatomy}

The stomach of the shark (Carcharhinus sorrah) is in the upper left body cavity. The stomach of the shark
(Carcharhinus sorrah) when seen from the ventral part is not visible because the gastric organs are covered by the liver.

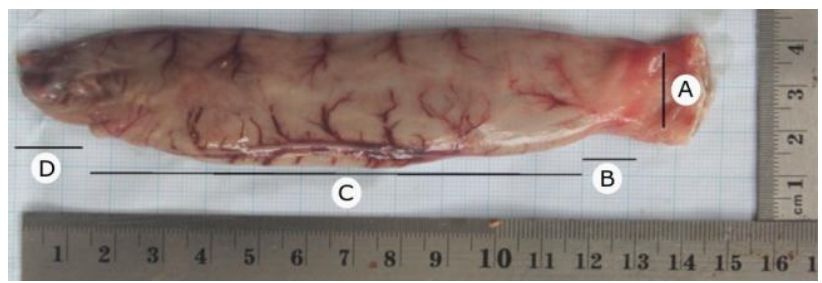

Figure 3. Anatomy of shark gastric organ: (A) Cardiac, (B) Fundus, (C) Body of the Stomach, (D) Pilorus.

\section{Anatomy of the Intestinal Organs}

The gut of the shark (Carcharhinus sorrah) when viewed from the ventral side, the intestine is almost invisible because most of its organs are covered by the liver. The intestine is the longest organ of the digestive tract of sharks. The central shark intestine is shaped like an elongated hollow tube, the total length of the intestine is $34.4 \mathrm{~cm}$. The intestine has a soft and supple texture.

The outer wall structure of the Carcharhinus sorrah small intestine is smooth and slippery. The small intestine of the shark (Carcharhinus sorrah) is characterized by narrowing of the cavity after the pylorus, then the boundary of the small intestine is marked by an enlarged cavity as a transition between the small intestine and large intestine. The small intestine Carcharhinus sorrah has a reddish color while the large intestine has a reddish white color. The inner part of the Carcharhinus sorrah intestine is almost evenly spotted bowel (fili). 


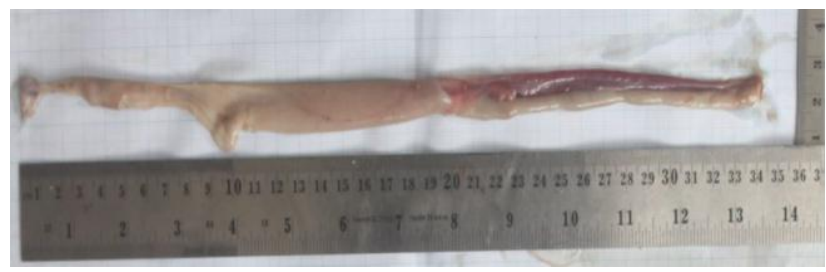

Figure 4. Anatomy of the Intestinal Organ (A) of a shark (Carcharhinus sorrah).

\section{Anatomy of the Liver}

The shark liver (Carcharhinus sorrah) are located at the anterior end of the body cavity. Shark's liver is located on the side of the abdomen, in the peritoneal cavity and covers the viscera. Shark's liver when seen from the ventral part, it is clearly seen all parts of the liver.

The observation of the liver anatomy of Carcharhinus sorrah shows that the liver is pink, soft, supple and slippery. The liver are elongated and flat on the sides. The liver is the largest organ in the shark's body. The total weight of the heart is $\mathbf{5 5 . 6}$ grams. The heart consists of two lobes. Liver anatomy in sharks appears to be smaller right lobe while the left lobe is larger. The length of the right lobe is $18.3 \mathrm{~cm}$.

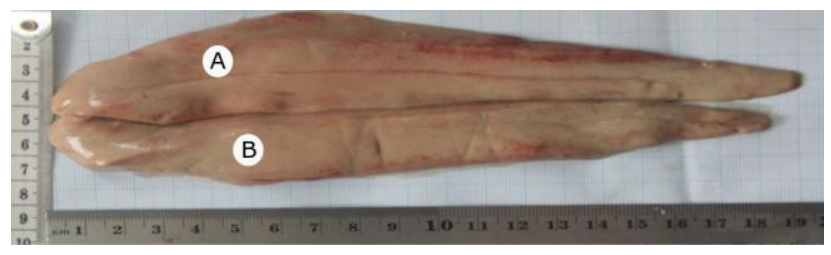

Figure 5. Anatomy of the Shark Liver: (A) Left lobe, (B) Right lobe.

\section{CONCLUSIONS}

The anatomy of shark gastric organs is slippery textured. The stomach is in the form of "J", colored reddish white, and has a flexible texture. The shark has a long and slender intestine, the intestine of the fish is a spiral valve. The shark spiral valve is divided into two parts. The liver anatomy of the species consists of two lobes, a larger left lobe. The shark's liver is elongated.

\section{ACKNOWLEDGMENTS}

The author would like to thank to the management of apprenticeship program of faculty of science and technology for guidance during the research, to the management of biology, medicine and natural product chemistry \& kaunia journal for assistance in paper writing.

\section{REFERENCES}

Abubakar, S., Beor, M and Sulistiono. 2013. Reproductive Biological Aspects of Spotted Pari (Neotrygon kuhlii) in the Sunda Strait Waters. Journal of Fisheries and Marine Technology of IPB. Vol.6 (2): 129-138.

Ayu, R.M., Arief, M and Amin, M.A. 2012. Provision of Feed with Different Crude Fiber Levels Against Digestive Power of Feed on Rebellious Fish and Fish Not Refined. Journal of Fisheries and Marine Affairs. Airlangga University. Vol 4 (2): 187-192.

Campbell, N. A., Reece, J. B., and Michell., L. B., 2003. Biology (5nd). Jakarta: Erlangga, 255.

Candramila, W., 2006. Composition, Diversity and Sexual Ratios of Fish Elasmobranchii Origin of the West Kalimantan Snapper River. Biology Journal of FMIPA Tanjungpura University. Vol 1 (2): 41-46.

Castro, P., and Huber, M., 1997. Marine Biology (2 Ed). New York: Mc Graw Hill International, 14: 143: 149: 150.

Dalahi, F., Subekti, S and Agustomo. 2014. Isolation and Identification of Bacteria Found in Digestive Channels of Gouramy (Osphronemus gouramy) with Different Commercial Feed. Journal of Fisheries and Marine Affairs, Airlangga University. Vol. 6 (1): 87-92.

Fahmi., 2003. Several Aspects of Biology of Cucut Fish. Journal Oceanna. Vol 28. (2): 21-29.

Fujaya, Y., 2004. Basic Fish Physiology Development of Fisheries Technology. Jakarta: Asdi Mahasatya, 171-120.

Geneser, F. (1994). Book of Volume 2 Histology Text. Translated by: Arifin Gunawijaya. Jakarta: Binarupa Aksara. 116-133.

Humason., 1979. Manual of Histology and Special Staining Technic. 2nd ed. The Blanskinston Devicions. New York: MC. Graw Hill Book Company Inc.: 243-248. 72

Imran, J., 2011. Aspects of Reproductive Biology of Stingrays (Dasyatis kuhlii Müller \& Henle, 1841) obtained at the Makassar Paotere Fish Auction Place. [Essay]. Fisheries Resources Management Study Program Fisheries Department, Hasanuddin University, Makassar.

Kalina, L.T., Dhahiyat, Y., and Herawati, T., 2012. Food Habits and Area of Fish Niche in Hulu Suangai Cimanuk, Garut Regency, West Java. Perikananan and Maritime Journal of Padjajaran University. Vol. 3 (3): 163-173.

Kamal, M.M., Ernawati, Y and Rahmah, Y. 2009. Variations in Morfoanatomy Structure of Digestive Organs and their Relation to Eating Strategies and Habits of Deep Sea Skill Fish Food (Lutjenidae Family). Journal of Indonesian Aquatic and Fisheries Sciences. Vol. 16 (1): 33-88.

Kardong, K. V. 2009. Comparative Anatomy, Function, Evolution. New York: Mc Grew Hill, Pg. 520-521.

Makmur, S., and Praseto, D., 2006. Eating Habits, Gonad Maturity Levels and Haruan Fish Fecundity (Channa striata BLOCH) on the Sambujur River Fisheries Sanctuary. Journal of Perairan and Fisheries Science. Vol 13 (1): 227-31.

Nafish, M., Zainuddin., And Masyitha, D. 2017. Histology of Digestion of Cork Fish (Channa striata). Journal of Veterinary Medicine Veterinary Education Study Program Syiah Kuala University. Vol. 01 (2): 196-202.

Nontji, A., 1987. Nusantara Sea (First Edition). Jakarta: Djambat, 210-215.

Nurul M.SU., Redjjeki.S., And Taufiq N.S.P.J., 2014. Study of Biology of Stingray (Dasatis sp) in TPI Tasik Agung Rembang. Journal of Marine Research. Vol. 2. (3): 79-85.

Rahayu, P and Sudibo, M., 2016. Morphological, Morphometric and Conservation Status of Sharks Found in Northern Sumatra. Journal of Bioscience, Department of Biology, Biology Stud Program. Medan State University. Vol. 2 (1): 1-7.

Rahmawati, A. 20013. Variety of Stingray Species in the South Coast of Yogyakarta Based on Fenetic and Molecular Analysis. [Essay]. Faculty of Biology, Gajah Mada University, Yogyakarta. 73 . 
THIS PAGE INTENTIONALI Y LEIT BLANK 